\title{
Política Urbana como Instituição: complexidades e limitações na implementação do Plano Diretor Participativo de Palmas (2007) para viabilizar uma mudança institucional
}

\author{
Sarah Afonso Rodovalho \\ Universidade Federal do Tocantins - Palmas - Tocantins - Brasil \\ ORCID: https://orcid.org/0000-0002-1998-3583 \\ Mônica Aparecida da Rocha Silva. \\ Universidade Federal do Tocantins - Palmas - Tocantins - Brasil \\ ORCID: https://orcid.org/0000-0002-3323-7712
}

\begin{abstract}
Resumo
Este artigo tem como objetivo analisar as complexidades e limitações enfrentadas na implementação do Plano Diretor Participativo de Palmas (2007) para viabilizar uma mudança institucional. Para tanto, utilizou-se o arcabouço teórico do novo institucionalismo, que se mostrou útil para compreensão da Política Urbana no Brasil após a Constituição Federal de 1988, como instituição. Assim foi possível utilizar a teoria geral da mudança institucional (TANG, 2011) como metodologia para analisar o Plano Diretor Participativo de Palmas (2007-2018) sob uma nova lente. Concluiu-se que, considerando as cinco fases da mudança institucional e o objetivo de garantir o cumprimento da função social da cidade e da propriedade urbana, o Plano Diretor Participativo de Palmas (2007) não foi instrumento suficiente para viabilizar uma mudança institucional na política urbana de Palmas. Nas duas últimas fases, a 4 de definição ou configuração das regras, compreendida pela aprovação da lei do Plano Diretor na Câmara Municipal e a 5 de legitimação, estabilização e reprodução da política, que é caracterizada pela implantação do Plano Diretor e Gestão Democrática, não foram completadas. Os obstáculos a mudança institucional se mostraram mais fortes em influenciar a condução destas etapas, mesmo com o avanço das regras formais instituídas por meio dos instrumentos urbanísticos e do sistema de planejamento e gestão urbanos do Estatuto da Cidade e do Plano Diretor Participativo de Palmas (2007).
\end{abstract}

Palavras-chave: Política Urbana. Plano Diretor Participativo. Palmas. Mudança Institucional. Teoria Institucional. 


\title{
Urban Policy as an Institution: complexities and limitations in the implementation of the Palmas Participatory Master Plan (2007) to enable institutional change
}

\begin{abstract}
This article aims to analyze the complexities and limitations faced in implementing the Palmas Participatory Master Plan (2007) to promote institutional change. For that, the theoretical framework of the new institutionalism was used, which proved to be useful for understanding Urban Policy in Brazil after the Federal Constitution of 1988 as an institution. Thus, it was possible to use the general theory of institutional change (TANG, 2011) as a methodology to analyze the Participatory Master Plan of Palmas (2007-2018) under a new lens. It was concluded that, considering the five phases of institutional change and the objective of guaranteeing the fulfillment of the social function of the city and urban property, the Participatory Master Plan of Palmas (2007) was not a sufficient instrument to enable an institutional change in urban policy in Palmas. In the last two phases, the 4 for defining or configuring the rules, comprised by the approval of the Master Plan law in the City Council and the 5 for legitimizing, stabilizing and reproducing the policy, which is characterized by the implementation of the Master Plan and Democratic Management, have been completed. The obstacles to institutional change proved to be stronger in influencing the conduct of these stages, even with the advancement of formal rules instituted through urban planning instruments and the urban planning and management system of the City Statute and the Participatory Master Plan of Palmas (2007).

Keywords: Urban Policy. Participatory Master Plan. Palmas. Institutional Change. Institutional Theory.

\section{Política Urbana como Institución: complejidades y limitaciones en la implementación del Plan Maestro Participativo de Palmas (2007) para posibilitar el cambio institucional}

\section{Resumen}

Este artículo tiene como objetivo analizar las complejidades y limitaciones enfrentadas en la implementación del Plan Maestro Participativo de Palmas (2007) para permitir el cambio institucional. Con este fin, se utilizó el marco teórico del nuevo institucionalismo, que resultó ser útil para comprender la Política Urbana en Brasil después de la Constitución Federal de 1988 como institución. Así, fue posible utilizar la teoría general del cambio institucional (TANG, 2011) como metodología para analizar el Plan Maestro Participativo de Palmas (2007-2018) bajo una nueva lente. Se concluyó que, considerando las cinco fases del cambio institucional y el objetivo de garantizar el cumplimiento de la función social de la ciudad y la propiedad urbana, el Plan Maestro Participativo de Palmas (2007) no fue un instrumento suficiente para permitir un cambio institucional en la política urbana. de palmas. En las últimas dos fases, las 4 para definir o configurar las reglas, comprendidas por la aprobación de la ley del Plan Maestro en el Ayuntamiento y las 5 para legitimar, estabilizar y reproducir la política, que se caracteriza por la implementación del Plan Maestro y la Gestión Democrática, han sido completados Los obstáculos al cambio institucional demostraron ser más fuertes al influir en la conducción de estas etapas, incluso con el avance de las reglas formales instituidas a través de instrumentos de planificación urbana y el sistema de planificación y gestión urbana del Estatuto de la Ciudad y el Plan Maestro Participativo de Palmas (2007).

Palabras clave: Política urbana. Plan maestro participativo. Palmas. Cambio institucional. Teoría Institucional. 


\section{Introdução}

Política Urbana é a tentativa do "Estado de atender às exigências de solução da problemática urbana que, por sua vez, caracteriza uma estrutura urbana histórica específica" (SCHMIDT 1983, p. 43). A Constituição Federal do Brasil de 1988 apresenta um capítulo contendo dois artigos (182 e 183) sobre a Política Urbana. Após 13 anos, houve a regulamentação destes artigos da Carta Magna com a aprovação no Congresso Nacional da Lei Federal $n^{\circ} 10.257 / 2001$, O Estatuto da Cidade. Esses marcos jurídicos legais representam a atual tentativa do Estado de resolver os problemas urbanos.

O Estatuto da Cidade tem por objetivo ordenar o pleno desenvolvimento das funções sociais da cidade e da propriedade urbana. Ou seja, é um conjunto de "normas de ordem pública e interesse social que regulam o uso da propriedade urbana em prol do bem coletivo, da segurança e do bem-estar dos cidadãos, bem como do equilíbrio ambiental” (BRASIL, 2001). A Constituição Federal e posterior regulamentação do Estatuto da Cidade determinam que uma série de municípios precisam elaborar Planos Diretores Participativos, delineando assim uma série de mudanças na prática de planejamento e gestão urbanos a serem realizadas. O Plano Diretor Participativo Municipal estabeleceu-se como o principal instrumento legal de planejamento para o desenvolvimento urbano nas cidades brasileiras, e o Conselho de Desenvolvimento Urbano como o principal instrumento da gestão participativa, responsável por garantir a implantação do plano (SOUZA, 2010).

Desse modo, o Plano Diretor Participativo Municipal constitui o instrumento básico da política de desenvolvimento e de expansão urbana nos municípios. Ele deve ser elaborado por meio da participação da população e aprovado por lei municipal. A propriedade urbana cumpre sua função social quando atende as exigências fundamentais de ordenação da cidade expressas no plano diretor (BRASIL, 1988). Assim, a elaboração de um plano diretor deve respeitar as diretrizes gerais previstas no Estatuto da Cidade, "assegurando o atendimento das necessidades dos cidadãos quanto à qualidade de vida, à justiça social e ao desenvolvimento das atividades econômicas" (BRASIL, 2001).

Palmas, a capital do estado do Tocantins, foi projetada em 1989 e teve seu primeiro Plano Diretor Participativo pós-Estatuto da Cidade aprovado pela Lei Municipal Complementar $n^{\circ} 155$ de 28 de novembro de 2007. A questão que orienta este estudo é em que medida esse Plano Diretor Participativo (2007) viabilizou uma mudança institucional na política urbana de Palmas?

Utilizou-se a abordagem da teoria institucional para realizar a análise do processo de construção e implementação do Plano Diretor Participativo na cidade de Palmas. O interesse por compreender como as instituições são criadas, se mantém e afetam o comportamento dos indivíduos tem sido ponto central das indagações sociológicas desde a fundação da Sociologia como ciência. Karl Marx, Max Weber e Emile Durkheim, os três fundadores da sociologia moderna, se preocuparam em explicar como as instituições dão forma ao comportamento e à história dos indivíduos (TANG, 2011; NEE, 2005). Segundo Tang (2011), a mudança institucional é uma força motriz central por trás das mudanças sociais e, portanto, o tema central em todos os principais campos das ciências sociais (HOLLINGSWORTH, 2000; NEE, 2005; PORTES, 2006; TANG, 2011, ARRETCHE, 2007). 
No entanto é possível observar que não há consenso quanto ao que se entende por instituição, ou mesmo por mudança institucional, pois esses conceitos são utilizados com significados diferentes (LEVI, 1991; HOLLINGSWORTH, 2000; TANG, 2011; HALL \& TAYLOR, 2003). A literatura especializada apresenta uma capacidade muito limitada de medir a taxa de mudança institucional, sendo também muito limitada a compreensão de como a sociedade constrói novas instituições (HOLLINGSWORTH, 2000; SCHNEIBERG e LOUNSBURY, 2008; LEVI, 1991; IMMERGUT, 2006).

Com a pretensão de utilizar abordagem da teoria institucional para a análise da política urbana pós-Estatuto da Cidade, esse artigo tem como objetivo analisar as complexidades e limitações enfrentadas na implementação do pelo Plano Diretor Participativo de Palmas (2007) para viabilizar uma mudança institucional.

\section{Novo Institucionalismo e as Instituições}

A teoria institucional é de interesse interdisciplinar de expressivo enfoque nos estudos das ciências sociais (HOLLINGSWORTH, 2000; NEE, 2005; PORTES, 2006; TANG, 2011). O estudo das instituições é pertinente à organização da sociedade de modo legal, ao estabelecimento da ordem social e ao controle do Estado e tem ganhado proeminência nos estudos em ciência política realizados no Brasil (ARRETCHE, 2007). A ciência política, em específico, se dedica ao estudo das instituições governamentais, principalmente pela competência delas em estabelecer, implementar e fazer cumprir as políticas públicas.

O vencedor do Prêmio Nobel em Economia, Douglas North (1990), definiu instituições como as limitações ou restrições criadas pelos homens que dão forma à interação humana, ou seja, as regras do jogo de uma sociedade. Entretanto, diversos outros autores criticaram e complementaram essa definição. Segundo Portes (2006), essa seria uma definição vaga, que abarca tudo, desde as normas incorporadas no processo de socialização até a coerção física. Definição, por sinal, bastante próxima da noção de influência externa sobre o comportamento dos atores apresentada por Durkheim há mais de um século, cuja proposta defende que as categorias do pensamento são construções culturais e sociais que precedem o pensamento propriamente dito.

Portes (2006) ressalta que cabe compreender quais são as características do contexto social que restringem a ação do homem racional. Arretche (2007), por sua vez, afirma que a contribuição principal está em identificar quais são as instituições que de fato limitam a ação humana, seus comportamentos e decisões e de que maneira, por meio de que processos e mecanismos, se configura essa limitação. Para compreender esta questão, Portes (2006) parte inicialmente da distinção de cultura e estrutura social.

Para o autor, a cultura incorpora os elementos simbólicos essenciais à interação humana. A compreensão mútua e a ordem são as esferas dos valores, dos marcos cognitivos e do conhecimento acumulado. Assim, os valores culturais, que representam os princípios morais gerais conferem direções concretas para a ação, ou seja, definem as normas como elementos restritivos. Já a estrutura social é composta por pessoas reais e que desempenham papéis ordenados em uma escala hierárquica de algum tipo. Essa é a esfera dos interesses individuais e coletivos 
respaldados por diferentes quantidades de poder, manifestando o poder, as estruturas de classes e as hierarquias de status como elementos importantes da estrutura social que influenciam o comportamento humano.

Por fim, o autor define que as instituições constituem o plano simbólico das organizações e são o conjunto de regras, escritas e informais, que governam as relações entre os ocupantes de papéis em organizações sociais como a família, a escola e demais áreas institucionalmente estruturadas da vida organizacional: a política, a economia, a religião, as comunicações e a informação e o ócio.

Tang (2011) complementa enfatizando que as instituições, além de restringirem, ao mesmo tempo também habilitam os agentes visto que em alguns momentos melhoram o bem-estar social. Sob a perspectiva sociológica, Berger e Berger (1994) definem instituição como um padrão de controle, uma programação imposta pela sociedade da conduta pessoal, extrapolando o sentido usual do termo que designa uma organização. Nee (2005) afirma que é importante ter uma definição de instituições apropriada para análise com base na perspectiva que enfatiza o efeito causal das estruturas sociais. Desse modo, as instituições envolvem atores que buscam interesses reais em estruturas institucionais concretas. Uma instituição, de acordo com essa visão, é definida como um sistema dominante de elementos informais e formais inter-relacionados - crenças compartilhadas e personalizadas, convenções, normas e regras - por meio dos quais os atores orientam suas ações quando buscam seus interesses.

Nee (1998; 2005), igualmente, destaca que embora North aponte para os elementos informais das instituições, é inegável a ênfase de seus estudos nas regras formais do jogo ou nas regras básicas de base previstas pelas constituições e pela lei. Nesse sentido, Nee defende que North relega crenças e normas a uma caixapreta de restrições informais, incapaz de mostrar como as regras informais e sua aplicação se combinam com regras formais para permitir, motivar e orientar o comportamento.

Ao analisar exemplos de normas e redes informais, Nee (1998) conclui que o informal oprime as regras formais do jogo e molda a ação, pois as redes baseadas em conexões pessoais servem para organizar o comportamento. Para o autor, aqui reside o problema: as regras formais são produzidas e aplicadas pelo Estado, por empresas ou outros para resolver os problemas da ação coletiva e por meio de sanções de terceiros, enquanto normas informais surgem e são reforçadas com base nas contínuas relações sociais. Assim, diferentemente das regras formais, o monitoramento das normas informais é intrínseco à relação social, e a execução ocorre informalmente como subproduto da interação social. As normas são regras implícitas ou explícitas de comportamento esperado que incorporam os interesses e preferências dos membros de um grupo ou de uma comunidade.

Por outro lado, Andrew Schotter (1981 apud HOLLINGSWORTH, 2000) argumenta que as instituições não são regras do jogo e sim o comportamento que se segue a partir de regras, ou seja, o que os atores fazem com as regras. Neste sentido, Hall e Taylor (2003) abordam três versões do novo institucionalismo na ciência política que, de uma maneira geral, destacam a relação entre as instituições e o comportamento. São elas: institucionalismo da escolha racional, institucionalismo sociológico e institucionalismo histórico. Este último é o de maior interesse para a presente discussão. 
O institucionalismo histórico atribui grande importância às relações de poder, principalmente em relações assimétricas de poder, com o enfoque na ideia de que o conflito entre grupos rivais pela apropriação de recursos é central na vida política, bem como a distribuição desigual do poder e dos recursos (HALL \& TAYLOR, 2003). Dessa forma, o principal fator a estruturar o comportamento coletivo diz respeito ao modo como a organização institucional da comunidade política e as estruturas econômicas entram em conflito, pois determinam quais interesses são privilegiados.

Esta versão do institucionalismo se dedica a compreender o modo como as instituições repartem o poder de maneira desigual entre os grupos sociais. Postula um mundo no qual as instituições conferem a certos grupos ou interesses um acesso desproporcional ao processo de decisão. Assim define instituição como "os procedimentos, protocolos, normas e convenções oficiais e oficiosas inerentes à estrutura organizacional da comunidade política ou da economia política" (HALL \& TAYLOR, 2003, p. 196).

Desse modo, as instituições atuam numa perspectiva em que os indivíduos procuram maximizar suas conquistas, e as instituições afetam o comportamento individual em função das informações sobre o comportamento dos outros atores. Em complemento, também atuam na perspectiva cultural a partir da ênfase de que o comportamento jamais é totalmente estratégico, sendo limitado pela visão de mundo própria do indivíduo, ou seja, mesmo reconhecendo a existência de um comportamento racional orientado para tais fins, a perspectiva cultural sublinha que os indivíduos recorrem também a modelos de comportamento já conhecidos.

As instituições fornecem modelos morais e cognitivos que permitem a interpretação e a ação. $O$ indivíduo é concebido como uma entidade profundamente envolvida num mundo de instituições composto de símbolos, de cenários e de protocolos que fornecem filtros de interpretação, aplicáveis à situação ou a si próprio, a partir dos quais se define uma linha de ação. Não somente as instituições fornecem informações úteis de um ponto de vista estratégico como também afetam a identidade, a imagem de si e as preferências que guiam a ação (HALL \& TAYLOR, 2003, p. 198).

Em geral, o institucionalismo histórico mergulha nos arquivos e documentos na busca de indícios sobre as razões pelas quais os atores se comportaram da maneira que se observa. Hollingsworth (2000) reconhece a importância da compreensão das condições sociais e cognitivas que levam ao cumprimento ou não das regras e das condições que levam a mudanças nas regras. Ainda que as normas, regras, hábitos, convenções e valores sejam capazes tanto de refletir como de moldar as preferências dos atores, construindo os quadros cognitivos através do hábito, são as instituições que fornecem um quadro cognitivo pelo qual os indivíduos podem lidar com sua realidade.

Immergut (2006) afirma que os autores do institucionalismo histórico também se dedicam a temas relativos aos interesses e partem da compreensão de que a representação de interesses é moldada pelos atores coletivos e instituições ao carregarem traços da própria história. Assim, as demandas políticas expressas quase nunca são um reflexo das preferências individuais, pois são influenciadas por fatores institucionais que decidem entre interesses conflitantes e quase sempre privilegiam alguns em detrimento de outros. O Estado não se submete aos 
interesses localizados na sociedade. As ações do Estado buscam reproduzir o controle de suas instituições sobre a sociedade para reforçar sua autoridade, seu poder político e sua capacidade de ação e controle, sobretudo ao se considerar que cada Estado tem uma capacidade própria historicamente condicionada em longo prazo. Nesse sentido, é possível sintetizar as definições apresentadas da seguinte forma (Quadro 1):

Quadro 1: Quadro síntese de definições de instituições por autor

\begin{tabular}{|c|c|}
\hline Autor & Definições de Instituições \\
\hline North (1990) & $\begin{array}{l}\text { Instituições como as regras do jogo de uma sociedade e como as limitações } \\
\text { planejadas pelos homens que dão forma à interação humana, podendo ser } \\
\text { acordos, códigos de conduta e normas de comportamento ou leis, ou seja, } \\
\text { regras formais e informais. }\end{array}$ \\
\hline Portes (2006) & $\begin{array}{l}\text { As instituições constituem o plano simbólico das organizações. São o conjunto } \\
\text { de regras, escritas e informais, que governam as relações entre os ocupantes de } \\
\text { papéis em organizações sociais como a família, a escola e demais áreas } \\
\text { institucionalmente estruturadas da vida organizacional: a política, a economia, a } \\
\text { religião, as comunicações etc. }\end{array}$ \\
\hline Tang (2011) & $\begin{array}{l}\text { As instituições, além de restringirem, ao mesmo tempo também habilitam os } \\
\text { agentes, visto que as instituições em alguns momentos melhoram o bem-estar } \\
\text { social. }\end{array}$ \\
\hline $\begin{array}{l}\text { Berger e } \\
\text { Berger (1994) }\end{array}$ & $\begin{array}{l}\text { Instituição como um padrão de controle, uma programação imposta pela } \\
\text { sociedade da conduta pessoal, extrapolando o sentido usual do termo que } \\
\text { designa uma organização. }\end{array}$ \\
\hline Nee (2005) & $\begin{array}{l}\text { Definida como um sistema dominante de elementos informais e formais inter- } \\
\text { relacionados - crenças compartilhadas e personalizadas, convenções, normas e } \\
\text { regras - através dos quais atores orientam suas ações quando buscam seus } \\
\text { interesses. }\end{array}$ \\
\hline $\begin{array}{l}\text { Schotter } \\
(1981)\end{array}$ & $\begin{array}{l}\text { As instituições não são regras do jogo e sim o comportamento que seguem a } \\
\text { partir de regras, ou seja, o que os atores fazem com as regras }\end{array}$ \\
\hline $\begin{array}{l}\text { Hall e Taylor } \\
(2003)\end{array}$ & $\begin{array}{l}\text { As instituições fornecem modelos morais e cognitivos que permitem a } \\
\text { interpretação e a ação. Sob uma perspectiva cultural, os indivíduos recorrem a } \\
\text { modelos de comportamento já conhecidos para definir uma linha de ação. }\end{array}$ \\
\hline $\begin{array}{l}\text { Hollingsworth } \\
(2000)\end{array}$ & $\begin{array}{l}\text { As condições sociais e cognitivas levam ao cumprimento ou não cumprimento } \\
\text { das regras. As normas, hábitos, convenções e valores tanto refletem como } \\
\text { moldam as preferências dos atores, construindo os quadros cognitivos através } \\
\text { do hábito. São as instituições que fornecem um quadro cognitivo pelo qual os } \\
\text { indivíduos podem lidar com sua realidade. }\end{array}$ \\
\hline
\end{tabular}

Fonte: autores citados, elaborado pelas autoras, 2018.

Desse modo, é possível compreender que a Política Urbana no Brasil é uma instituição, prevista pelos artigos 182 e 183 da Constituição Federal, regulamentada pelo Estatuto da Cidade e aplicada por meio dos Planos Diretores Municipais. No entendimento aqui defendido, estes instrumentos são um conjunto de regras formais da sociedade que restringem e habilitam a interação humana, configurando um padrão de controle para a conduta pessoal, que governam as relações e sobre as quais os atores orientam suas ações. (NORTH, 1990; TANG, 2011; BERGER \& BERGER, 1994; PORTES, 2006; NEE, 2005). Entretanto, o comportamento que se segue a partir das regras, ou seja, se as regras são ou não cumpridas, é o ponto mais importante para a realidade urbana que se apresenta (SCHOTTER, 1981; HOLLINGSWORTH, 2000). 
Nos processos de planejamento e gestão urbanos e seus rebatimentos na configuração do espaço urbano é de vital importância ressaltar os aspectos informais (NEE, 2005). Nesse sentido, é possível destacar a existência das regras informais que fornecem os modelos de comportamentos morais e cognitivos. Estes são estabelecidos por uma perspectiva cultural por meio de normas, hábitos, convenções e valores que refletem e moldam a ação dos atores (HALL \& TAYLOR, 2003; HOLLINGSWORTH, 2000).

\section{A Teoria Geral da Mudança Institucional como Método de Análise}

Além da relação entre as instituições e o comportamento dos indivíduos, bem como do papel das instituições em determinados resultados sociais e políticos, a teoria institucional também busca explicar qual é o motivo que leva as instituições a se modificarem. Cabe esclarecer que como as normas, regras e valores são duráveis, eles desempenham um papel importante na formação da história das sociedades, contribuindo assim para a dependência da trajetória.

O institucionalismo histórico defende que o desenvolvimento é profundamente dependente da trajetória, e que as instituições são um dos principais fatores a condicionar este percurso (HALL \& TAYLOR, 2003). Neste sentido, há no fluxo dos eventos históricos períodos de continuidade e momentos de mudanças institucionais importantes que determinam um novo trajeto. Isso quer dizer que mesmo que os atores tentem se adaptar ao seu ambiente contemporâneo e às propostas de mudança, o legado histórico de normas, regras e valores influencia as decisões que tomam, pois eles são produtos do passado (HOLLINGSWORTH, 2000).

North (1990) afirma que instituições já estabelecidas geram poderosos incentivos que reforçam sua própria estabilidade, isto é, uma vez estabelecidas, as instituições são difíceis de mudar mesmo quando elas são socialmente ineficientes. A perspectiva de North influenciou o trabalho de Putnam (2000), ao concluir que os contextos sociais que condicionam as instituições e seu funcionamento desenvolvem-se ao longo da história. Este desenvolvimento ocorre de maneira subordinada à trajetória, em que o lugar a que se pode chegar depende do lugar de onde se veio. Desse modo, simplesmente é impossível chegar a certos lugares a partir de onde se está.

As definições de dependência da trajetória (Quadro 2) apresentam aspectos importantes para a análise da mudança institucional específica na Política Urbana Brasileira. As instituições, sejam formais ou informais, são duráveis, pois uma vez estabelecidas, são difíceis de mudar. Como essas instituições são profundamente importantes na formação da história das sociedades, elas são condicionantes da trajetória. Assim, o conjunto de interações já existentes influenciam as possibilidades de implementação de novos arranjos, tornando as novas trajetórias dependentes das anteriores.

As novas instituições políticas têm alto custo para serem criadas, pois os atores sociais assumem compromissos de acordo com as instituições e políticas existentes e isso aumenta drasticamente os custos de transação e as possíveis mudanças. Adicionalmente, Pierson (2000) destaca outros dois obstáculos às mudanças nas instituições políticas como os horizontes temporais de curto prazo 
para os atores políticos e o forte viés de manutenção do status quo das instituições políticas. Como a maior parte das grandes mudanças institucionais ocorrem normalmente em longo prazo, a maioria dos atores políticos não se interessa em tomar decisões políticas desta natureza, preferindo ações de curto prazo devido à lógica eleitoral. Por outro lado, a incerteza política na sucessão faz com que os atores políticos criem regras difíceis de serem revertidas, resultando em um obstáculo à mudança institucional, o que reforça as dificuldades de sistemas políticos de sair da trajetória dependente.

Quadro 2: Quadro síntese de definições de dependência da trajetória por autor

\begin{tabular}{|l|l|}
\hline Autor & Definições de dependência da trajetória \\
\hline $\begin{array}{l}\text { Hollingsworth } \\
\text { (2000) }\end{array}$ & $\begin{array}{l}\text { As normas, regras e valores são bastante duráveis e desempenham um papel } \\
\text { importante na formação da história das sociedades, contribuindo assim para a } \\
\text { dependência da trajetória. }\end{array}$ \\
\hline $\begin{array}{l}\text { Hall e Taylor } \\
\text { (2003) }\end{array}$ & $\begin{array}{l}\text { O desenvolvimento histórico é profundamente dependente da trajetória, e as } \\
\text { instituições são um dos principais fatores a condicionar esta trajetória, pois } \\
\text { elas são as responsáveis por estruturar a resposta de uma dada nação aos } \\
\text { novos desafios. }\end{array}$ \\
\hline Pierson (2000) & $\begin{array}{l}\text { Tem sentido de retornos crescentes, ou seja, a probabilidade de novos passos } \\
\text { na mesma trajetória aumenta a cada passo dado nesta trajetória. Quanto mais } \\
\text { os efeitos começam a se acumular, eles geram um círculo vicioso (ou virtuoso) } \\
\text { de atividades. }\end{array}$ \\
\hline North (1993) & $\begin{array}{l}\text { Instituições já estabelecidas geram poderosos incentivos que reforçam sua } \\
\text { própria estabilidade e desenvolvimento posterior, pois uma vez estabelecidas, } \\
\text { as instituições são difíceis de mudar. }\end{array}$ \\
\hline Putnam (2000) & $\begin{array}{l}\text { O lugar a que se pode chegar depende do lugar de onde se veio e } \\
\text { simplesmente é impossível chegar a certos lugares a partir de onde se está. }\end{array}$ \\
\hline
\end{tabular}

Fonte: autores citados, elaborado pelas autoras, 2018.

Levi (1991) afirma que, como a estrutura de poder não é a mesma para todos os atores envolvidos em uma instituição, aqueles indivíduos que exercem uma maior dominação possuem meios e interesse em manter os arranjos institucionais vigentes se eles forem satisfatórios e reformar somente aqueles indesejáveis. Schneiberg e Lounsbury (2008), em seus estudos sobre os movimentos sociais e sua relação com a análise institucional, ressaltam que os atores habilitados pelas instituições existentes usam suas vantagens para elaborar instituições de forma a preservar o seu poder e impedir alternativas. Em suma, a mudança institucional apresenta vários obstáculos principalmente relacionados ao alto custo político, horizontes temporais, manutenção do status quo e interesse do grupo dominante em preservar o poder.

A mudança institucional pode ser compreendida essencialmente como um processo de selecionar algumas ideias dentre muitas e solidificá-las em instituições. A competição entre as ideias e a luta pelo poder de fazer as regras estão muitas vezes no cerne da mudança institucional (TANG, 2011). Levi (1991) afirma que a mudança institucional implica em redistribuição de poder. Ela explica que transformar instituições é uma tarefa árdua, principalmente para aqueles considerados mais fracos e com pouco poder de barganha, sendo o principal instrumento de poder a capacidade de organização coletiva.

Schneiberg e Lounsbury (2008) ressaltam que grupos que procuram a mudança frequentemente se mobilizam coletivamente para afirmar novas lógicas e 
perturbar os arranjos existentes. Para eles, este processo é uma arena da vida social. Novas instituições e arranjos institucionais são tipicamente construídos a partir dos escombros ou destroços de instituições anteriores, pois sistemas novos não são criados frequentemente de uma só vez. Em vez disso, os caminhos podem surgir por meio de múltiplas ondas ao longo do tempo por meio de sequências ou estágios sucessivos que elaboram e inovam em realizações anteriores parciais. $O$ ponto central para a criação de novos campos e trajetórias é algum tipo de mobilização coletiva ou movimento, não apenas uma única explosão de organização, mas também ondas ou ciclos de mobilização e formação organizacional.

Tang (2011), quando propõe a teoria geral da mudança institucional, afirma que o processo de mudança institucional consiste em cinco fases distintas: (1) a geração das ideias para arranjos institucionais específicos; (2) a mobilização política; (3) a luta pelo poder de conceber e ditar disposições institucionais, ou seja, definir as regras específicas; (4) a definição ou configuração das regras; e (5) legitimação, estabilização e reprodução. A primeira fase é composta pela geração de novas ideias advindas, por exemplo, do surgimento de novas pesquisas científicas, mudanças culturais e comportamentais, dentre outras. Posteriormente, na segunda e terceira fases, é que surgem os aspectos relacionados ao conflito político de seleção das ideias para que na quarta fase haja o ajuste real das regras a ser realizado pelo grupo vencedor da luta pelo poder. Na última fase é que o novo arranjo institucional tem sua utilidade testada no sistema social para avaliar se o novo arranjo realmente é capaz de melhorar o bem-estar da maioria da população.

O autor destaca neste processo um ponto crítico. Mesmo que o novo arranjo seja legítimo, falta poder suficiente e indispensável para socializá-lo e internalizá-lo nos indivíduos, ou seja, é necessário que o agente dominante da mudança continue a apoiar o novo arranjo ou que nenhuma força contrária o desafie para que ele possa existir, operar e se reproduzir. Nesse sentido, a questão-chave para compreender uma mudança institucional eficiente é entender como os processos intelectuais e políticos interagem para moldar o resultado da mudança (TANG, 2011).

Para análise realizada neste artigo, foi utilizada a teoria geral da mudança institucional (TANG, 2011), para compreender as complexidades e limitações enfrentadas pelo Plano Diretor Participativo de Palmas (2007) para viabilizar uma mudança institucional. As cinco fases descritas por Tang foram adaptadas aos processos de planejamento e gestão urbanos a serem efetivados nos municípios após a aprovação do Estatuto da Cidade (Quadro 3).

Quadro 3: Quadro comparativo das fases da mudança institucional e mudança nos processos municipais de planejamento e gestão urbanos após o Estatuto da Cidade

\begin{tabular}{|l|l|l|}
\hline \multicolumn{2}{|l|}{$\begin{array}{l}\text { Fases da Mudança Institucional (TANG, } \\
\mathbf{2 0 1 1} \text { ) }\end{array}$} & $\begin{array}{l}\text { Mudança nos processos municipais de } \\
\text { planejamento e gestão urbanos após o Estatuto da } \\
\text { Cidade }\end{array}$ \\
\hline $\mathbf{1}$ & $\begin{array}{l}\text { A geração das ideias para arranjos } \\
\text { institucionais específicos }\end{array}$ & $\begin{array}{l}\text { Elaboração do Plano Diretor } \\
\text { (Diagnóstico, Diretrizes, Propostas) }\end{array}$ \\
\hline $\mathbf{2}$ & Mobilização política & $\begin{array}{l}\text { Processos Participativos, reuniões comunitárias e } \\
\text { setoriais }\end{array}$ \\
\hline $\mathbf{3}$ & $\begin{array}{l}\text { Luta pelo poder de conceber e ditar } \\
\text { disposições institucionais }\end{array}$ & $\begin{array}{l}\text { Audiências públicas e comunitárias participativas, } \\
\text { para aprovação das propostas e projeto de lei }\end{array}$ \\
\hline
\end{tabular}




\begin{tabular}{|c|l|l|}
\hline $\mathbf{4}$ & $\begin{array}{l}\text { A definição ou configuração das } \\
\text { regras }\end{array}$ & $\begin{array}{l}\text { Aprovação da lei do Plano Diretor na Câmara } \\
\text { Municipal }\end{array}$ \\
\hline $\mathbf{5}$ & $\begin{array}{l}\text { Legitimação, estabilização e } \\
\text { reprodução }\end{array}$ & Implantação do Plano Diretor e Gestão Democrática \\
\hline
\end{tabular}

Fonte: Tang, 2011, elaborado pelas autoras, 2018.

Assim, no contexto da análise das fases da mudança institucional, considerando os processos municipais de planejamento e gestão urbanos após o Estatuto da Cidade, é possível considerar a elaboração do Plano Diretor (diagnóstico, diretrizes e propostas) como marco central na geração das ideias para as mudanças que seriam sugeridas na realidade urbana. A mobilização política é enfatizada pela necessidade dos processos participativos, reuniões comunitárias e setoriais, cuja sequência é marcada por audiências públicas e comunitárias participativas como espaços de deliberação nos quais os conflitos e a luta pelo poder de conceber e ditar as disposições institucionais se expressam. A definição ou configuração final das regras cabe à Câmara Municipal no processo de aprovação da lei do Plano Diretor que deve ser seguido de audiências públicas. Por fim, tem-se a legitimação, estabilização e reprodução das mudanças institucionais propostas, tempo de testar os novos arranjos que nos processos municipais de planejamento e gestão urbanos se caracterizam pela fase de implantação do plano diretor e monitoramento por parte da gestão democrática.

$\mathrm{Na}$ prática de planejamento e gestão urbanos, mesmo que os planos diretores municipais consigam determinar a política urbana, há dificuldades para aprovar mudanças efetivas sob forma de lei. Ainda assim, caso aprovadas, há a dificuldade de implementar as novas práticas. Essas dificuldades estão relacionadas aos comportamentos dos atores em assimetria de poder que reforçam a dependência da trajetória, travando as diversas fases da mudança institucional proposta. A teoria da mudança institucional, como instrumento de análise, permite verificar em quais momentos da trajetória histórica houve avanços em selecionar e solidificar ideias que efetivamente melhoraram o bem-estar da população e em quais houve a falta de poder necessário para legitimar, operacionalizar e reproduzir o novo arranjo, como os planos diretores municipais.

A teoria institucional revela-se bastante útil no sentido de apresentar o arcabouço suficiente para a compreensão das dificuldades enfrentadas pelo Estatuto da Cidade no sentido de efetivar as mudanças institucionais por ele propostas especialmente relacionadas na contemporaneidade ao momento de teste da capacidade de melhorar a qualidade de vida da população do novo arranjo institucional, caracterizado pelos processos municipais de planejamento e gestão urbanos, de elaboração e implementação dos Planos Diretores Municipais.

\section{A formação do Estado do Tocantins e a sua herança política}

Para analisar possibilidades da mudança institucional ocasionadas pela política urbana em Palmas é necessário resgatar os pilares históricos da formação do Estado do Tocantins. A separação do então Norte goiano e a consequente construção da cidade nova planejada para ser sua capital revela intensa ligação com o ideário desenvolvimentista. Por um lado, havia o discurso pela busca da ruptura 
com o passado de decadência econômica, e "por outro, tem a cultura política do Estado empenhada na manutenção do poder de decisão da elite dominante" (MACHADO, 2011, p. 30).

Rodrigues, Oliveira (2013) e Lira (1995) destacam que entre 1830 e 1930 havia a forte presença de coronéis fazendeiros criadores de gado no cenário da região do Norte de Goiás, que somente começou a sofrer rupturas em meados do século XX. Lira (1995) reforça que, nas décadas de 1960 e 1970, o padrão de ocupação e a política fundiária permaneciam cristalizados no modelo colonial e encontraram no latifúndio o modo de ampliação e acumulação de capital na região.

A nova Constituição Federal do Brasil, aprovada em 5 de outubro de 1988, na qual foi criado oficialmente o estado do Tocantins teve o apoio da elite agrária, principalmente grandes pecuaristas de Goiás e Tocantins. Entretanto, conforme esclarece Machado (2011), o desejo de romper com esse passado e caminhar rumo à modernidade e desenvolvimento sucumbiram frente à forte estrutura social oligárquica e latifundiária.

Uma pesquisa realizada sobre a atuação dos deputados federais do Tocantins, no período de 1989 até 2011, apontou que, após sete mandatos eleitorais, o poder legislativo se preocupou muito mais em homologar decisões do executivo ou homenagear alguma figura pública do que apresentar proposições de políticas públicas voltadas para o desenvolvimento do estado (CILLI e ROCHA SILVA, 2017).

Nesse sentido, a criação legal do estado do Tocantins no momento de maior efervescência da cidadania insurgente (HOUSTON, 2013) nos grandes centros urbanos, que fez incluir na mesma Constituição Federal as premissas da política urbana, não impactou de maneira significativa a experiência de construção e formação da capital do Tocantins. O peso da cultura política marcante no país e no então estado de Goiás, se expressou na formação do novo estado e de sua nova capital, reforçando desenvolvimento socioespacial dependente da trajetória (RODOVALHO, 2020).

Nos primeiros anos de construção e implantação da cidade de Palmas, o governo do Estado do Tocantins foi o principal agente fundiário, com a justificativa de viabilizar a construção da capital, fomentou a dispersão urbana, a especulação fundiária e a segregação socioespacial (RODOVALHO, 2012). O Estado desapropriou de forma atropelada diversas propriedades rurais e com atos de despossessão criou novas matrículas cartoriais sobre aquelas que não conseguiu desapropriar (LUCINI, 2018). Essas terras foram na sequência comercializadas como terra urbana com altos valores de renda sobre elas, e a implantação da cidade seguiu a lógica da disponibilidade de terras a serem vendidas ou doadas e não o planejamento realizado pelo Projeto Urbanístico da cidade (1989), em fitas e fases, que levaria à otimização da cara infraestrutura a ser instalada (VELASQUES, 2010; RODOVALHO, 2012)(

Figura $1 \mathrm{e}$ 
Figura 2).

Figura 1: As fases previstas para a ocupação de Palmas - TO em seu Projeto Urbanístico e Macroparcelamento de Palmas - TO. As fases eram definidas pelo sítio urbano de modo que os córregos configuravam os limites

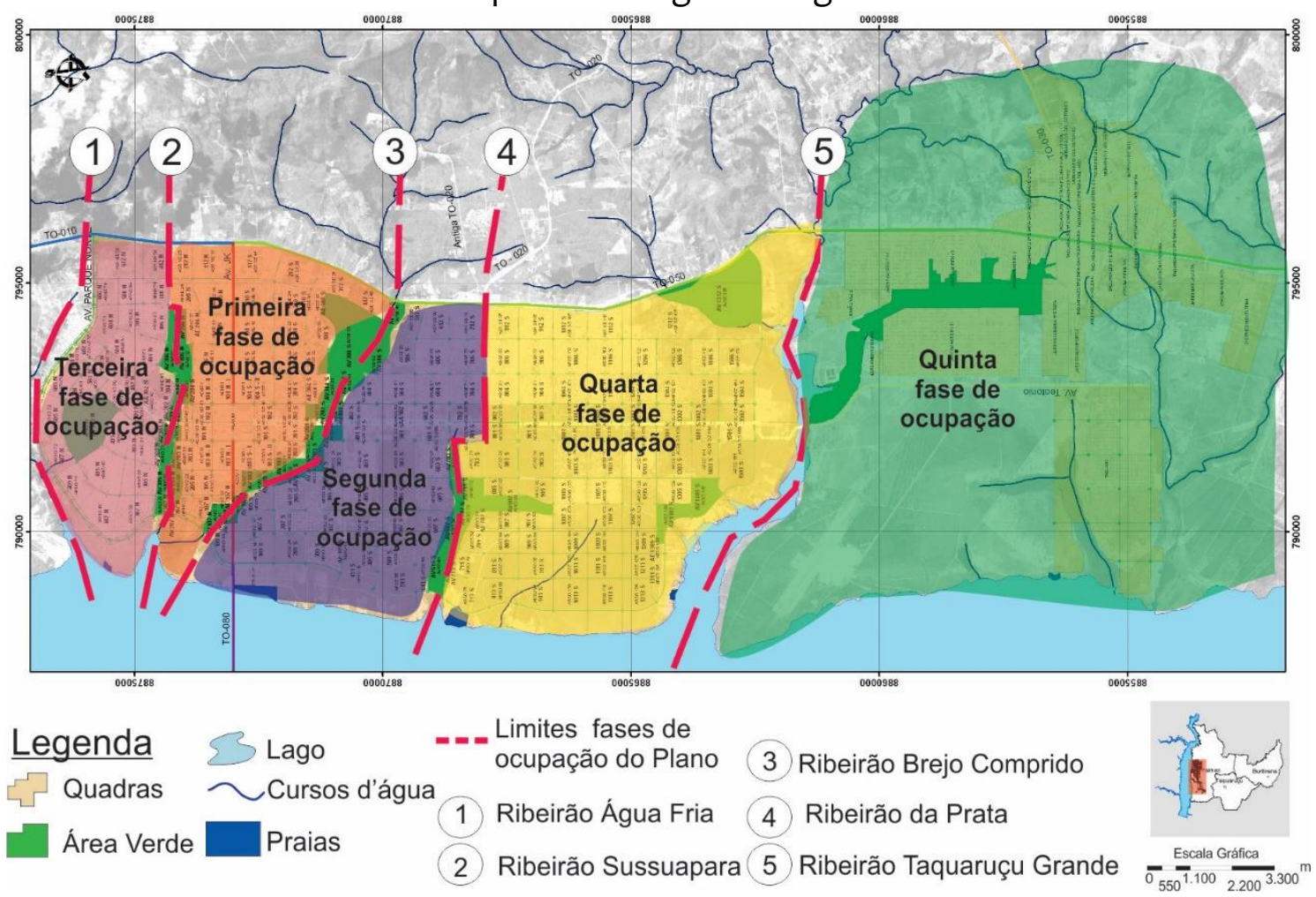

Fonte: SEDUH, 2005 adaptado pelas autoras, 2019. 
Figura 2: Mapa de Ocupação das Quadras que demonstra que as quadras foram microparceladas e tiveram seu início de ocupação sem respeitar as fases de ocupação previstas no Projeto Urbanístico

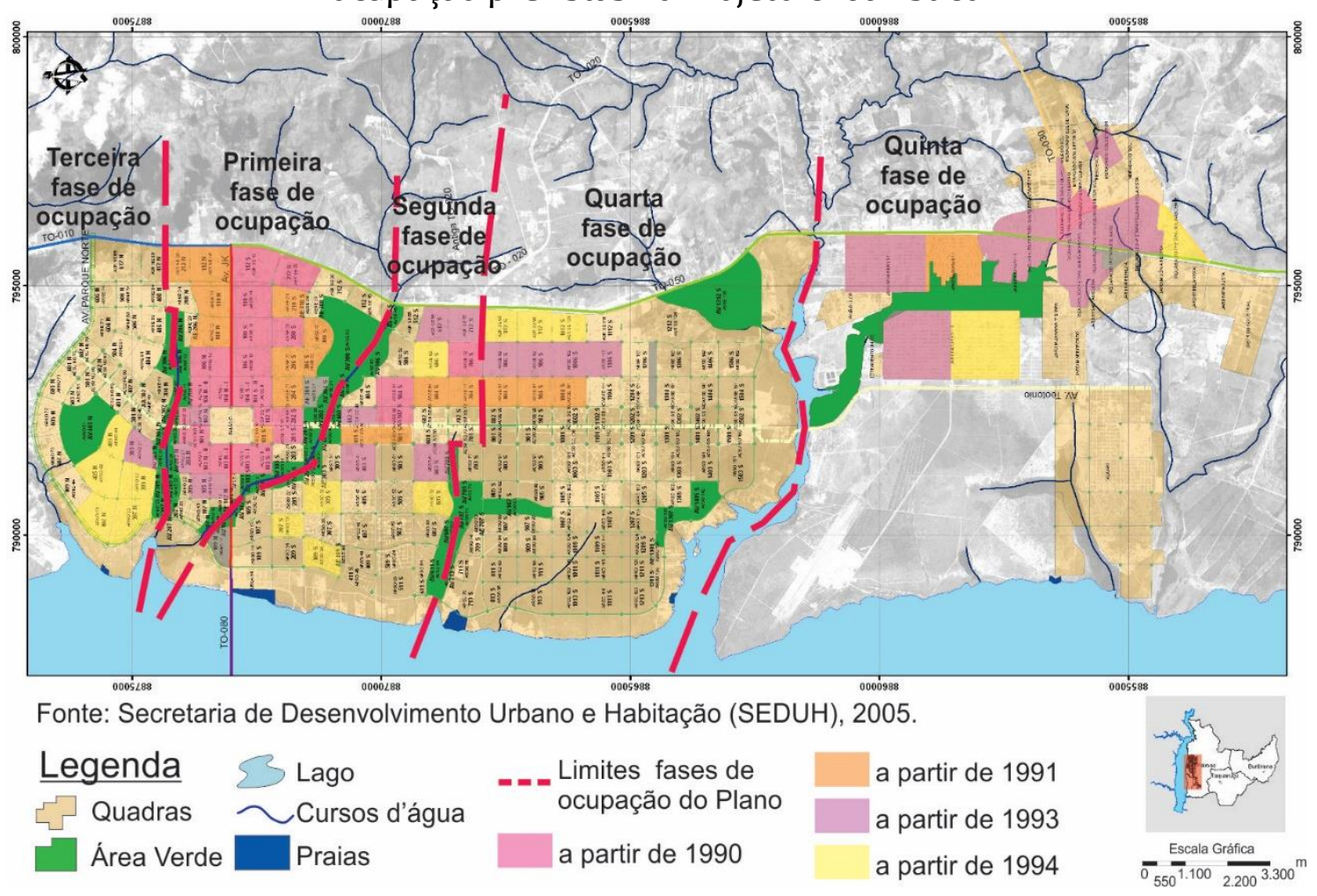

Fonte: Rodovalho, 2012.

A não implementação do projeto urbanístico da cidade em sua completude e a inserção marginal da população de baixa renda no processo de produção do espaço urbano (RODOVALHO, 2012), bem como a insegurança jurídica sobre as irregularidades fundiárias fomentaram em Palmas a cultura política da desconfiança (RODOVALHO, 2020). Baquero e González (2016, p. 497) esclarecem que a relação entre democracia e qualidade de vida é bidirecional, ou seja, é preciso responder às demandas dos cidadãos, pois "dependendo do grau de respostas sociais, o apoio à democracia e suas instituições pode aumentar ou diminuir. Quando um padrão de demandas não atendido se materializa, também se constitui uma cultura política de desconfiança", bem como gera uma predisposição nas pessoas em não acreditar, e muito menos confiar, na consolidação de uma cultura política cidadã ativa (BAQUERO (2008).

Os processos de não atendimento das demandas da população continuaram com o passar dos anos em Palmas. A trajetória da política habitacional nos anos subsequentes, anterior ao Plano Diretor Participativo de Palmas (2007), foi de locação dos projetos de habitação de interesse social nas franjas urbanas (AMARAL, 2009; MELO JÚNIOR, 2008). Foi por meio de programas gerenciados pela administração pública que houve a ampliação do povoado de Taquaralto, a criação dos Jardins Aurenys I, II, III e IV, seguidos pelo Jardim Taquari na segunda etapa de ocupação da cidade. Esses bairros ficaram localizados em regiões mais distantes da 
área fruto do projeto urbanístico original que ainda se encontrava com baixa densidade ocupacional.

A partir dos anos 2000, observa-se o reforço da dispersão urbana, da segregação socioespacial e especulação fundiária e imobiliária em duas frentes. A primeira relativa às ações do Estado em fomentar o uso turístico e residencial de alto padrão nas margens do Lago de Palmas (VIEIRA, 2019). Nesse sentido, destacase o Projeto Orla e a parceria público-privada Orla S.A., responsável pelo loteamento denominado Orla 14 que alterou o uso de Área de Lazer e Cultura para Uso Residencial/Comercial da margem do lago (Figura 3). A Lei Complementar $n^{\circ}$ 58/2002, também permitiu loteamentos de uso residencial em área de expansão urbana fora da área do projeto urbanístico original da cidade, que ainda era de baixa densidade ocupacional.

A segunda frente, foi ainda mais além no sentido de dispersar a área urbanizada de influência da capital, e de abrir novas fronteiras para a renda da terra por meio da especulação fundiária/imobiliária. Com o represamento do reservatório da UHE Luiz Eduardo Magalhães, o reassentamento de famílias ribeirinhas que tiveram suas terras inundadas e a construção da ponte sobre o Lago de Palmas, a região do Distrito de Luzimangues, no município de Porto Nacional, passa por um intenso processo de parcelamento do solo urbano (PINTO, 2012) (Figura 4). É neste cenário que se inicia a elaboração do Plano Diretor Participativo de Palmas em 2005.

Figura 3: Palmas: ocupação do solo, com destaque para as Áreas de Lazer e Cultura em laranja, onde se localiza o parcelamento de alto padrão Orla 14; o Jardim Taquari em vinho, reservado para a população de mais baixa renda
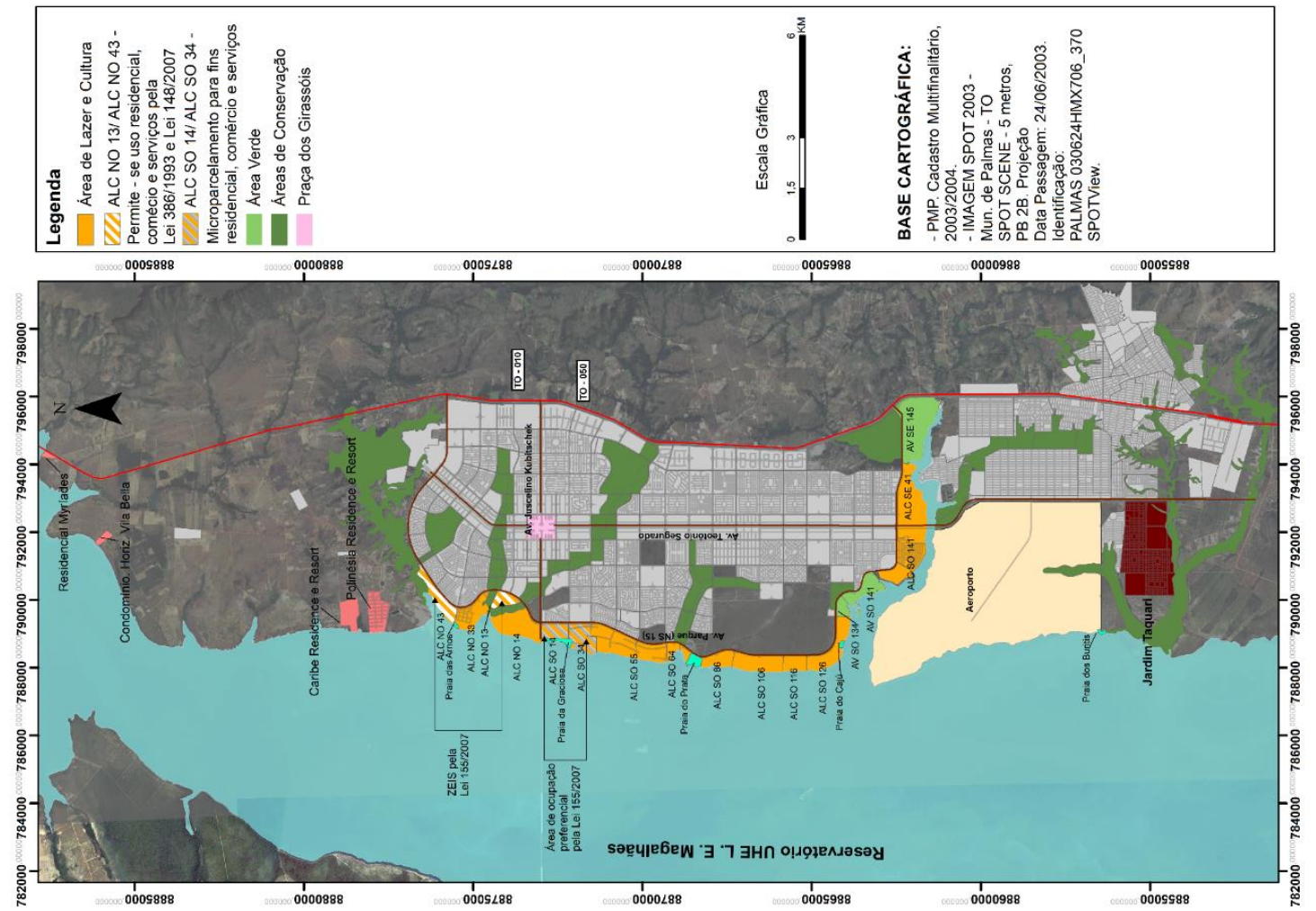

Fonte: VIEIRA, 2019. 
Figura 4: Histórico de Microparcelamento em Luzimangues em relação a Palmas. Em branco, parcelamentos registrados até 2000. Em amarelo, de 2004 a 2006. Em laranja, até 2009 e em vermelho, até 2014

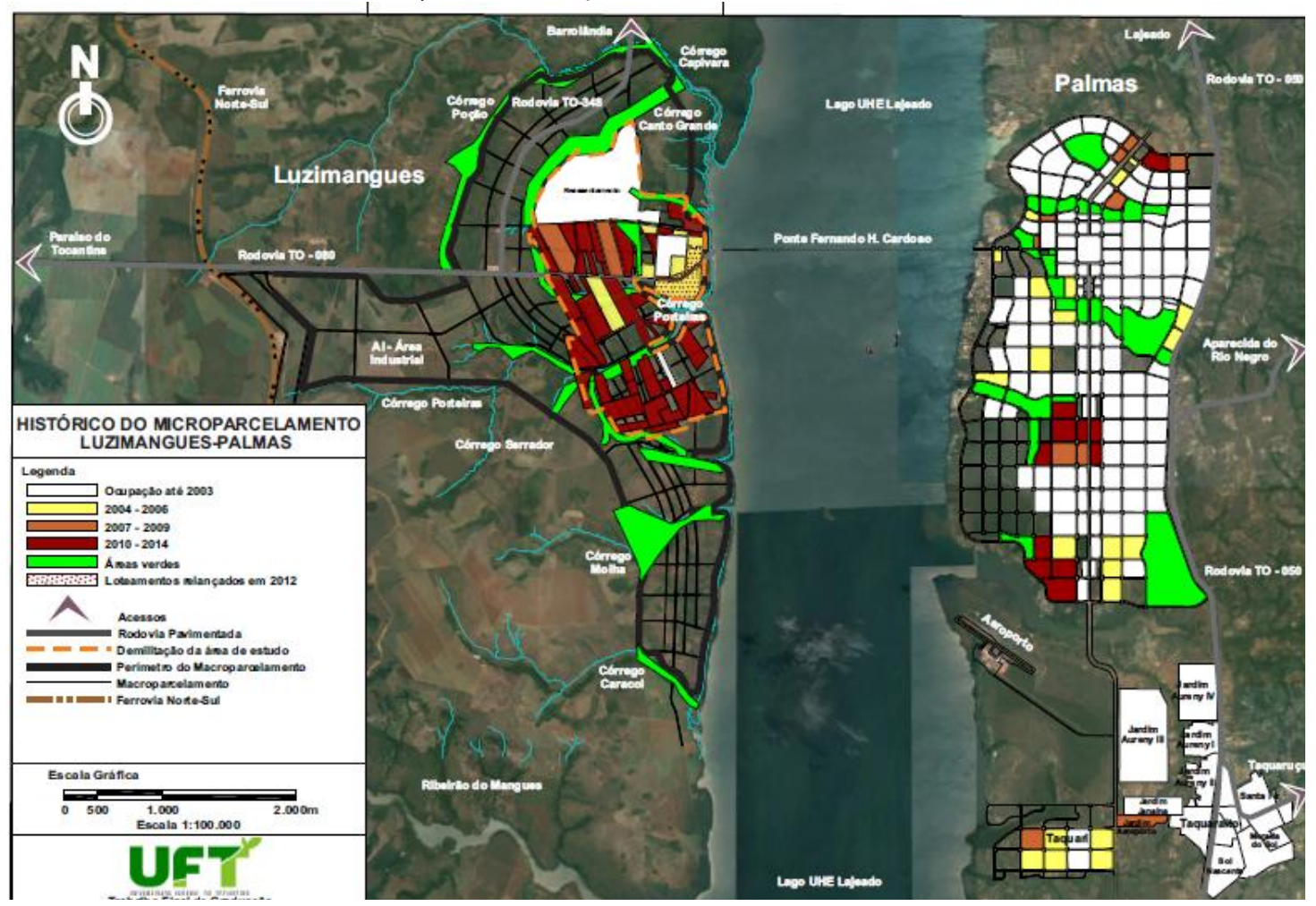

Fonte: Barreto, 2016.

Baquero (2008) argumenta que existe uma relação causal recíproca permanente entre instituições deficientes que não produzem cidadãos com predisposições democráticas, e estes, por sua vez, distanciam-se e mostram desapego por essas instituições por não acreditarem nos seus objetivos e desconfiarem de suas intenções. Tal ciclo vicioso é observado nos processos de planejamento e gestão urbanos em Palmas, desde a não implementação do Projeto Urbanístico à implementação da política urbana pós-estatuto da cidade (RODOVALHO, 2020).

\section{Análise da Mudança Institucional da Política Urbana em Palmas}

Para aprofundar no processo de implementação da política urbana na capital por meio do Plano Diretor Participativo de Palmas (2007-2018) e o seu processo de desenvolvimento urbano pós-Estatuto da Cidade, é preciso avaliar as diversas ações de planejamento e gestão urbanos no período em estudo, considerando as fases da mudança institucional nos processos de planejamento e gestão urbanos em Palmas pós-Estatuto da cidade com destaque para o caso do Plano Diretor Participativo de Palmas de 2007.

O Plano Diretor Participativo de Palmas (PDPP) (2007) foi o primeiro Plano Diretor elaborado e implementado em Palmas pós-Estatuto da Cidade. Nas fases 1 (da geração das ideias para arranjos institucionais específicos), 2 (de mobilização política), e 3 (luta pelo poder de conceber e ditar disposições institucionais), 
observa-se a tentativa em seguir a metodologia participativa proposta pelo Estatuto da Cidade e reconhece-se que foram realizadas com relativo sucesso.

A geração das ideias para os novos arranjos institucionais, compreendida pela etapa de elaboração do Plano Diretor (diagnóstico, diretrizes, propostas) ocorreu de maneira fundamentada e apoiada na mobilização política, por meio de processos participativos e reuniões comunitárias e setoriais. A prefeitura municipal realizou capacitação com seus técnicos e representantes da sociedade civil organizada, contou com apoio da Universidade Federal do Tocantins (UFT) e de consultoria externa (RODOVALHO, ROCHA SILVA E RODRIGUES, 2019).

A luta pelo poder de conceber e ditar as disposições institucionais entendidas como as audiências públicas e comunitárias participativas ocorreram como o determinado pelo Estatuto da Cidade. Por mais que a participação nas instituições de deliberação conjunta foi se enfraquecendo no decorrer do processo, foi inegável a importância dessa experiência de democracia deliberativa para a cidade (RODOVALHO, ROCHA SILVA E RODRIGUES, 2019).

Essas primeiras três fases, fomentadas pelas práticas da cidadania insurgente (HOLSTON, 2013) foram realizadas e completadas de modo que essa prática teve influência em garantir que parte da sociedade civil permanecesse atenta aos processos da gestão democrática, principalmente nas alterações e revisão do PDPP (2007), buscando sempre manter a metodologia de planejamento participativo proposta pelo Estatuto da Cidade.

$\mathrm{Na}$ fase 4, de definição ou configuração das regras, compreendida como a aprovação da lei do Plano Diretor na Câmara Municipal, é que começam a se evidenciar os maiores obstáculos à mudança institucional. Duas grandes alterações no Projeto de Lei enviado do executivo, destacam a manutenção da especulação imobiliária em que pese a piora da segregação socioespacial.

Primeiro, houve redução considerável nas Zonas Especiais de Interesse Social (Zeis) propostas no projeto de Lei ( 
Política Urbana como Instituição: complexidades e limitações na implementação do Plano Diretor Participativo de Palmas (2007) para viabilizar uma mudança institucional

Figura 5), por meio de emendas ao projeto realizadas na Câmara, contrariando as deliberações democráticas realizadas nas fases anteriores. 
Figura 5: Mapa com a identificação no espaço urbano de Palmas das áreas definidas como Zeis na elaboração e aprovação do Plano Diretor Participativo de Palmas (2007) e situação após a aprovação da Lei na Câmara de Vereadores. Destaque para as áreas em laranja e amarelo não aprovadas

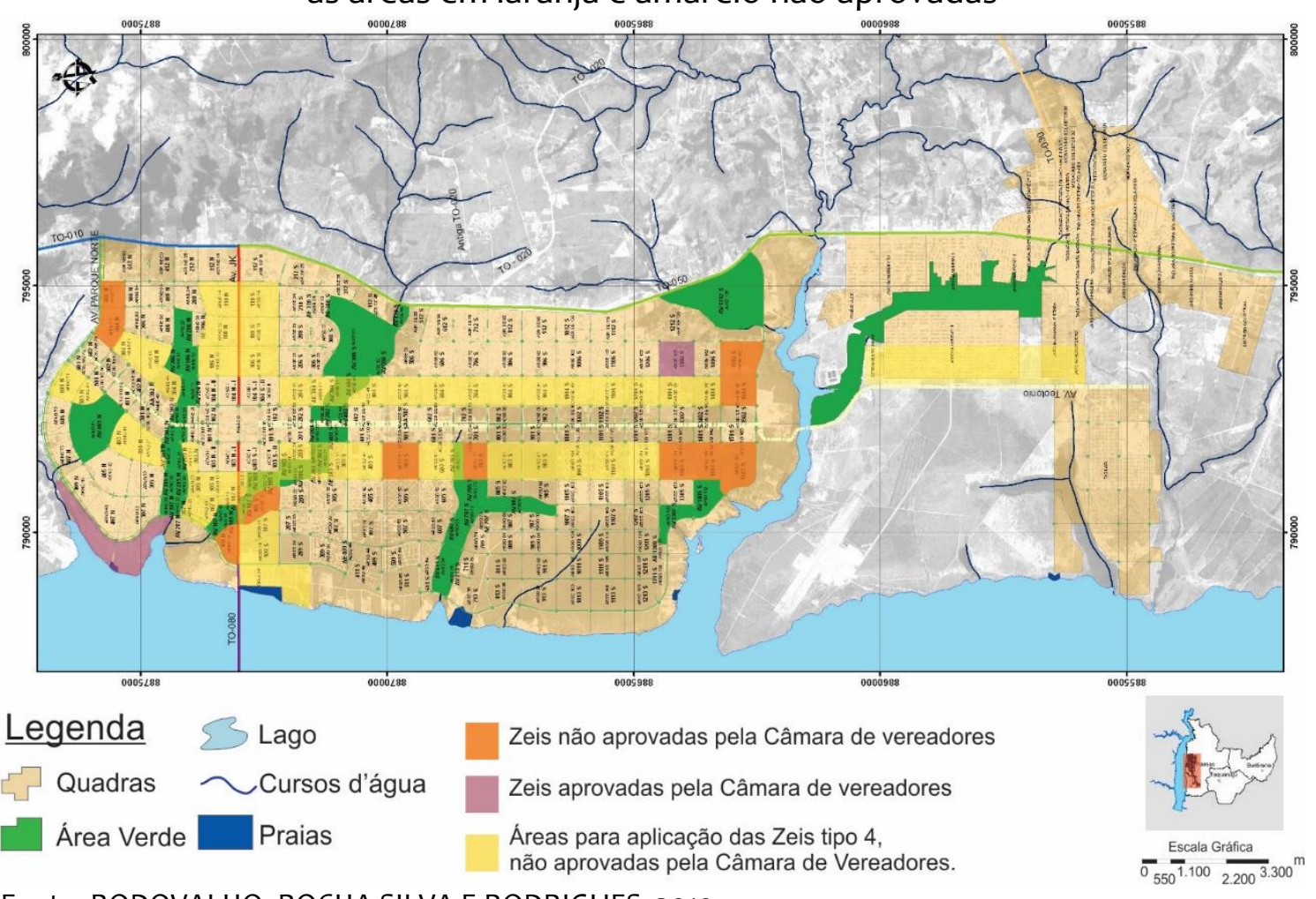

Fonte: RODOVALHO, ROCHA SILVA E RODRIGUES, 2019.

Várias das Zeis do Tipo 1 - aquelas que destinava glebas urbanas, públicas ou particulares, para fins de loteamentos de interesse social, em áreas já dotadas de infraestrutura - bem como a totalidade das Zeis do tipo 4 - aquela que previa o uso de lotes multifamiliares vazios e/ou subutilizados ao longo da avenida Teotônio Segurado e da Avenida JK - não foram aprovadas, sendo excluída da versão final da lei. Mesmo considerando que seria necessária ainda uma regulamentação dos procedimentos para a aplicação desse instrumento, seriam de grande relevância as possibilidades de aumento na densidade ocupacional na região central da cidade. Esse instrumento reduziria a especulação imobiliária relativa a essas áreas e o preço da terra, possibilitando a inserção de programas habitacionais em áreas dotadas de infraestrutura urbana, reduzindo a segregação socioespacial e contribuindo com a redução do custo de vida como, por exemplo, os custos relacionados à mobilidade urbana.

As possibilidades de mudança no desenvolvimento urbano da cidade são expressivas nesse ponto. Pois, quando se inicia a elaboração do Plano Diretor Participativo, a principal ação de planejamento e gestão urbanos da prefeitura se dava no sentido de promover programas de habitação de interesse social, geralmente localizados na região de Palmas Sul. Com a aprovação do PDPP, essa realidade não se alterou de maneira efetiva. Logo nos primeiros anos de vigência dele, o PMCMV foi instituído pelo governo federal e houve grandes incentivos para 
a construção de habitação. As habitações destinadas ao público de baixa renda, em sua maioria, foram localizadas em regiões periféricas no extremo sul da cidade, principalmente por não haver quase nenhuma oferta de Zeis para construção de habitações localizadas próximas ao centro urbano. O PMCMV impulsionou o mercado de terra valorizando seus preços de compra e venda. Nesse momento, o distrito de Luzimangues, localizado no município de Porto Nacional e na margem esquerda do rio Tocantins, vizinho a Palmas, passa por processo acelerado de parcelamento e comercialização de lotes urbanos. Muitos dos compradores desses lotes são moradores de Palmas que não conseguem adquirir seus terrenos na capital altamente especulada.

Outra alteração foi a criação das Áreas de Urbanização de Interesse Turístico (AUIT), que se destaca por caminhar no sentido contrário à redução do perímetro urbano da cidade proposta pelo PDPP. Essa Área de Urbanização de Interesse Turístico nas margens do Lago de Palmas possibilita meios legais para construção de condomínios fechados de uso residencial, em áreas fora do perímetro urbano. Ressalta-se o fato de que o aumento da área urbanizável e urbanizada reduz a densidade de ocupação urbana e aumenta os custos de implantação e manutenção da infraestrutura urbana. Além disso, esses condomínios fechados são destinados a uma parcela da sociedade de mais alta renda, aumentando a fragmentação do tecido urbano, ainda privatizando e restringindo o acesso ao reservatório da UHE. Do ponto de vista das regras formais do Estatuto da Cidade, a aprovação das Zeis e a redução do perímetro urbano seriam o caminho para ampliação da garantia da função social da propriedade urbana e da cidade, bem como o direito à moradia e ao acesso à infraestrutura e equipamentos comunitários.

Na fase 5 de legitimação, estabilização e reprodução da política urbana, que consiste na implementação do Plano Diretor e da gestão democrática da cidade, é que se evidencia que o Plano Diretor Participativo de Palmas (2007) não foi um instrumento suficiente para viabilizar uma mudança institucional completa na política urbana de Palmas. A baixa efetividade na implementação do PDPP (2007) (RODOVALHO, ROCHA SILVA E RODRIGUES, 2019), bem como seu processo conflituoso de revisão (RODOVALHO e ROCHA SILVA, 2019), evidenciou na não garantia da função social da cidade e da propriedade urbana em Palmas, objetivo fim do Estatuto da Cidade.

As leis complementares necessárias à aplicabilidade do plano não foram todas elaboradas, as leis urbanísticas que necessitavam de revisão não foram revistas, os planos setoriais não foram aprovados, os investimentos prioritários não foram considerados e os espaços da gestão democrática foram esvaziados. Demostrando que seguir com os princípios, diretrizes e propostas contidos no Plano Diretor não foi a prioridade das ações de planejamento e gestão urbanos realizadas pelas administrações municipais (RODOVALHO, ROCHA SILVA E RODRIGUES, 2019).

Como ponto positivo, destaca-se a primeira lei complementar a regulamentar um dos instrumentos do PDPP, que foi a Lei Complementar $n^{\circ} 195$ de 22 de dezembro de 2009, que regulamentou Parcelamento, Edificação ou Utilização Compulsórios (PEUC) o Imposto sobre a Propriedade Predial e Territorial Urbana 
(IPTU) Progressivo no Tempo e a Desapropriação com Pagamento em Títulos. Entretanto, mesmo regulamentada, os instrumentos não entraram em vigor, sendo que as notificações do PEUC só foram ocorrer em 2013 e o primeiro lançamento de IPTU Progressivo se deu no exercício de 2015.

Em 2011, na tentativa de regularização de uma importante Zeis prevista no PDPP, a Zeis Santo Amaro, alguns grupos políticos encontraram espaço para fazer campanha em prol da expansão do perímetro urbano da cidade. As discussões, nesse aspecto, se prolongaram e não alcançaram sucesso, sendo o perímetro mantido depois de muitas manifestações sociais (BAZOLLI, 2012). Destaca-se neste momento a organização da sociedade civil que garantiu o cumprimento de uma parcela das regras formais relacionadas à tentativa de ampliação do perímetro urbano. Esse processo político teve a participação da administração municipal e da Câmara de Vereadores com um projeto de lei e emendas que tentavam ampliar a dispersão urbana e a especulação imobiliária em Palmas.

Após 2013, a gestão municipal mostrou ser mais atuante em um modelo de planejamento estratégico que se contrapõe às mudanças propostas pelo Estatuto da Cidade. No ano de 2013, a prefeitura criou o Instituto Municipal de Planejamento Urbano de Palmas (IMPUP) para dar conta do planejamento urbano, incluiu a cidade na Iniciativa Cidades Emergentes e Sustentáveis do Banco Interamericano do Desenvolvimento (ICES/BID) para a elaboração do Plano de Ação Palmas Sustentável e iniciou a elaboração do Projeto BRT Palmas. Estes projetos desconsideram as diretrizes e determinações do PDPP (2007) e reforçaram a dispersão urbana, a ampliação da especulação fundiária e imobiliária e a manutenção da segregação socioespacial.

No início de 2015, o BRT Palmas caminhava para a licitação e o Plano de Ação Palmas Sustentável estava em suas últimas audiências de aprovação ( 
Figura 6). Quando a prefeitura anunciou o início do processo de revisão do PDPP de maneira acelerada e precipitada como uma das metas apresentadas no Plano de Ação Palmas Sustentável. Estas pautas - BRT Palmas, Plano de Ação Palmas Sustentável e Revisão do PDPP - foram desenvolvidas ao mesmo tempo, entretanto não foram discutidos em conjunto como propostas complementares como deveria ser. A Revisão do PDPP deveria ser a responsável pelo diagnóstico da cidade real, levantamento das demandas e eleição das prioridades. A partir do Plano Diretor, um plano de mobilidade deveria ser elaborado coletiva e democraticamente no qual as opções de modais mais adequados para a cidade seriam escolhidas. 
Figura 6: Linha do tempo relacionando Ações Externas à Administração Municipal e Outras Ações de Planejamento de Gestão Urbanos em 2015

Ações externas a Administração

Municipal em 2015

Entre agosto e novembro de 2015 - parte do imóvel matrícula ${ }^{\circ} 22.099$ foi vendido

17.09.2015 - MPF ajuizou Ação Civil Pública em favor da suspensão da licitação do BRT

30.09.2015 - divulgação da Carta ao CMDUH feita por grupos de pesquisa da UFT

$\underline{01.10 .2015 \text { - Primeiro fórum Palmas Participa }}$

02.10.2015 - Justiça Federal concedeu medida cautelar para evitar desembolso financeiro da CAIXA em favor do BRT Palmas Sul

06.10.2015 - MPE emitiu Recomendação n ${ }^{\circ}$ $01 / 2015$

$\underline{09.10 .2015 \text { - reunião na UFT com o }}$ prefeito e professores e representantes do Palmas Participa

23.10.2015 a 01.11.2015 - Jogos Mundiais Indigenas

23.10.2015 - data do contrato do MASTERPLAN

09.12.2015 - Lei Complementar n ${ }^{\circ} 328$ regularização ZEIS Santo Amaro

17.12.2015 - PF recebe a denuncia de um dos proprietários da área sudoeste matricula $\mathrm{n}^{\circ} 22.099$

19.12.2015 - Lei Complementar n ${ }^{\circ} 344$ criação da ZEIS Jardim Canaã

\section{Outras Ações de Planejamento de Gestão Urbanos em 2015}

02.06.2015 - Audiência Pública com as famílias impactadas com as desapropriações do BRT

Decreto $n^{\circ} 1042 / 2015$ e o Decreto $n^{\circ} 1066 / 2015$ aprovou o microparcelamento dos Condomínios Fechados Alphaville Palmas 1 e 2.

06.08.2015 - Decreto $\mathrm{n}^{\circ}$ 1.089/2015 instituiu o Grupo de Trabalho para a Revisão do PDPP

21.08.2015 - Lei Complementar $\mathrm{n}^{\circ} 322$ autoriza desafetação de áreas publicas para desapropriações do BRT Palmas Sul

01.09.2015 - primeira apresentação pública no CEULP/ULBRA da revisão do PDPP

Setembro de 2015 - Anuncio de R\$ 3 bilhões em investimentos para Palmas por meio do BID/ICES

23.09.2015 - reunião no CEULP/ULBRA sobre a revisão do PDPP

24.09.2015 - publicação de aviso de audiência pública para a revisão do PDPP, dias 14, 15 e 16 de outubro

30.09.2015 - reunião no CMDUH para aprovar a revisão do PDPP.

08.10.2015 - Plano de Ação Palmas Sustentável foi entregue pela CAIXA, BID/ICES

12.10.2015 - prefeitura cancelou as audiências marcadas para a revisão do PDPP

16.10.2015 - O processo licitatório do BRT Palmas Sul foi suspenso

24.11.2015 - Lei Complementar n 327 criou o Programa Palmas Solar

27.11.2015 - Decreto $\mathrm{n}^{\circ} 1.151 / 2015$ instituiu comissão especial para a Revisão do PDPP

11.12.2015 - Foi aprovado a contratação do BRT Palmas Centro

Elaborado pela autora, 2019 
Neste sentido que uma parcela da sociedade civil se organizou para esclarecer as necessidades de cumprimento da metodologia prevista pelo Estatuto da Cidade e resoluções do ConCidades. Este grupo foi formado por aqueles mais interessados na política urbana e suas demandas participativas, principalmente acadêmicos e profissionais, arquitetos, urbanistas, planejadores urbanos e operadores do direito urbanístico. Mesmo pequeno, se comparado à totalidade da população, suas ações e mobilizações foram vitais no sentido de esclarecer e pautar a organização do processo de revisão do PDPP. A ação da sociedade civil organizada que instigou a ação dos órgãos de controle foi marcante e primordial para condução do processo de revisão do PDPP mais participativo (RODOVALHO e ROCHA SILVA, 2019).

Em que pese, o destaque ao valoroso trabalho da sociedade civil organizada em mobilizar agentes e órgão de controle de modo a garantir processos de planejamento mais participativos, o resultado da lei apresentada ao legislativo e aprovada em 2018 ainda se mostrou bastante influenciado pelos projetos anteriores (BRT Palmas e Plano de Ação Palmas Sustentável). Desse modo, é possível concluir que a experiência da política urbana de Palmas pós-Estatuto da Cidade foi incipiente em completar a mudança institucional que foi proposta pelas regras formais. Não se mostrou eficiente em fazer cumprir a função social da cidade e da propriedade urbana bem como não ampliou os espaços deliberativos de planejamento participativo e gestão democrática da cidade.

\section{Considerações Finais}

O objetivo deste artigo foi analisar as complexidades e limitações enfrentadas pelo Plano Diretor Participativo de Palmas (2007) para viabilizar uma mudança institucional. Para tanto, utilizou-se o arcabouço teórico do novo institucionalismo, que se mostrou útil para compreensão da Política Urbana no Brasil após a Constituição Federal de 1988 como instituição. Assim foi possível utilizar a teoria geral da mudança institucional (TANG, 2011) como metodologia para analisar o Plano Diretor Participativo de Palmas (2007-2018) sob uma nova lente.

O Plano Diretor Municipal é um conjunto de regras formais que habilitam e restringem a interação humana no espaço das cidades. Esse conjunto de regras fornece um padrão de controle para a conduta pessoal. Ele deveria governar as relações e orientar a ação dos atores modeladores do espaço. Entretanto, o comportamento que se espera a partir da definição e aprovação dessas regras nem sempre ocorre. Existem aspectos informais, ideologias, interesses pessoais de quem tem muito recurso de poder, hábitos, convenções e valores, construídos historicamente, que refletem e moldam a ação dos atores políticos e privados e que, consequentemente, afetaram o desenvolvimento da política urbana em Palmas. Dessa forma, o desenvolvimento das sociedades e o desenvolvimento urbano mostram-se condicionados pelas instituições formais e informais. 
A mudança institucional enfrentou desafios e obstáculos para se estabelecer por causa das relações assimétricas de poder que tendem a manter o status quo e da diferença nos horizontes temporais. Alterar uma regra formal é mais simples e rápido do que alterar regras informais construídas no decorrer do tempo e já enraizadas na cultura. As decisões políticas anteriores tendem a moldar e influenciar as decisões subsequentes, reforçando os mesmos padrões e processos socioespaciais de configuração do espaço urbano.

Vale destacar que a mudança institucional precisa ser entendida como um processo que demanda tempo para ser completada, sendo que a maior parte dela ocorre quase sempre em longos prazos. Há necessidade de romper diversos obstáculos tais como: as estruturas sociais e políticas estabelecidas e a manutenção do status quo compactuadas por atores públicos e privados que têm seus próprios interesses e, ao mesmo tempo, capacidade de influenciar as regras do jogo com os processos de dominação e pelas relações de poder.

Assim, considerando as cinco fases aqui descritas e o objetivo de garantir o cumprimento da função social da cidade e da propriedade urbana, conclui-se que o Plano Diretor Participativo de Palmas (2007) não foi instrumento suficiente para viabilizar uma mudança institucional completa na política urbana de Palmas. Nas duas últimas fases, a 4, a que trata da definição ou configuração das regras, compreendida pela aprovação da lei do Plano Diretor na Câmara Municipal e a 5 , que versa sobre a legitimação, estabilização e reprodução da política, que é caracterizada pela implantação do Plano Diretor e Gestão Democrática, não foram completadas. Os obstáculos a mudança institucional se mostraram mais fortes em influenciar a condução destas etapas, mesmo com o avanço das regras formais instituídas por meio dos instrumentos urbanísticos e do sistema de planejamento e gestão urbanos do Estatuto da Cidade e do Plano Diretor Participativo de Palmas (2007).

\section{REFERÊNCIAS}

AMARAL, F. O. M. do. Especulação Imobiliária e Segregação Social em Palmas do Tocantins: Uma Análise a Partir dos Programas Habitacionais no Período de 2000 a 2008. Dissertação (Mestrado em Arquitetura e Urbanismo). Universidade de Brasília, FAU/UNB. 2009.

ARRETCHE, M. A agenda institucional. Revista Brasileira de Ciências Sociais, São Paulo, v. 22, n. 64, p. 147-151, 2007.

BAQUERO, M. Democracia formal, cultura política informal e capital social no Brasil. Opinião Pública, Campinas, vol. 14, n² 2, p.380-413, novembro, 2008.

BAQUERO, M.; GONZÁLEZ R. S. Cultura política, mudanças econômicas e democracia inercial. Uma análise pós-eleições de 2014. Opinião Pública, Campinas, vol. 22, nº 3, p. 492-523, dezembro, 2016. 
BARRETO, M. F. Luzimangues: caracterização e análise urbana. Trabalho Final de Graduação (Bacharelado em Arquitetura e Urbanismo) - Curso de Arquitetura e Urbanismo, Universidade Federal do Tocantins, CAU/UFT, Palmas, 2016.

BAZOLLI, J. A. Dispersão Urbana e Instrumentos de Gestão: dilemas do poder local e da sociedade em Palmas - TO. Tese (Doutorado em Geografia). Universidade Federal de Uberlândia - UFU. Uberlândia-MG, 2012.

BERGER, P.; BERGER, B. O que é uma instituição social? In: FORACCHI, M.; MARTINS, J. de S. (ORG.). Sociologia e Sociedade: leituras de introdução à Sociologia. 21 ed. Rio de Janeiro: LTC, 1994.

BRASIL. [Constituição (1988)]. Constituição da República Federativa do Brasil de 1988. Brasília: Presidência da República, 1988. Disponível em: http://www.planalto.gov.br/ccivil_03/constituicao/constituicaocompilado.htm. Acesso 01 mai. de 2019.

BRASIL. Estatuto da Cidade - Lei Federal nº 10.257 de 10 de julho de 2001. Regulamenta os artigos 182 e 183 da Constituição Federal, que estabelecem diretrizes gerais da política urbana e dão outras providências. Brasília: Presidência da República, 2001. Disponível em:

http://www.planalto.gov.br/ccivil_03/leis/leis_2001/l10257.htm. Acesso 01 mai. de 2019.

CILLI, Michelle A. L.; ROCHA SILVA, Mônica A.. Poder Legislativo e Desenvolvimento: uma análise das proposições de parlamentares do estado do Tocantins. In: CILLI, Michelle A. L.; ROCHA SILVA, Mônica A. Poder político e políticas públicas: desafios e dimensões contemporâneas do desenvolvimento. Palmas-Tocantins: EDUFT, 2017.

HALL, P. A.; TAYLOR, R. C. R. (2003). As três versões do neo-institucionalismo. Lua Nova. Online, n. 58, pp 193-223. Disponível em: http://dx.doi.org/10.1590/S010264452003000100010. Acesso em: 15 ago 2016.

HOLLINGSWORTH, J. R. Doing institutional analysis: implications for the study of innovations. In: Review of International Political Economy, Vol 7, No. 4, Winter, 2000. pp. 595-644.

HOLSTON, J. Cidadania Insurgente: disjunções da democracia e da modernidade no Brasil. São Paulo: Companhia das Letras, 2013.

IMMERGUT, E. O Núcleo Teórico do Novo Institucionalismo. In: SARAIVA, E. FERRAREZI, E. Políticas Públicas, Brasília: ENA, 2006.

LEVI, M. Uma lógica da mudança institucional. Dados - Revista de Ciências Sociais, Rio de Janeiro, v. 34, $\mathrm{n}^{\circ}$ 1, 1991. 
LIRA, E. R. A Gênese de Palmas - Tocantins. Dissertação (Mestrado em Desenvolvimento Regional e Planejamento Ambiental) - Faculdade de Ciências e Tecnologia, Universidade Estadual Paulista - FCT-UNESP: Presidente Prudente, 1995.

LUCINI, A. C. G. C. Palmas, no Tocantins, terra de quem? As desapropriações e despossessões de terras para a implantação da última capital projetada do século XX. 2018. Tese (Doutorado em Ciências do Ambiente) - Programa de Pós-Graduação em Ciências do Ambiente, Universidade Federal do Tocantins, Palmas, 2018.

MACHADO, T. R. O poder do atraso na produção do espaço urbano: caso de Palmas, Tocantins. Tese (Doutorado em Geografia). Universidade Federal Fluminense. UFF: Niterói - RJ, 2011.

MELO JÚNIOR, L. G. de. CO YVY ORE RETAMA: DE QUEM É ESTA TERRA? Uma avaliação da segregação a partir dos programas de habitação e ordenamento territorial de Palmas. Dissertação (Mestrado em Arquitetura e Urbanismo). Universidade de Brasília, FAU/UNB. 2008.

NEE, V. Norms and Networks in Economic and Organizational Performance. In: The American Economic Review, Vol. 88, No. 2, 1998. pp. 85-89.

NEE, V. The New Institutionalisms in Economics and Sociology. In: SMELSER, N. J.; SWEDBERG, R., (ed). The Handbook of Economic Sociology - $2^{\text {a }}$ ed. Princeton University Press: New York, 2005.

NORTH, D. Instituciones, cambio institucional y desempeño económico. Cidade do México: Fondo de Cultura Económica. 1990.

PALMAS. Lei Complementar $\mathbf{n}^{\circ} 155$ de 28 de dezembro de 2007. Dispõe sobre a política urbana do município de Palmas, formulada para atender ao pleno desenvolvimento das funções sociais da cidade e a garantia do bem-estar de seus habitantes, conforme estabelece a Constituição Federal/88, em seus arts. 182 e 183, e o Estatuto da Cidade, Lei Federal n. 10.257, de 10 de julho de 2001. Palmas, 2007. Disponível em: https://legislativo.palmas.to.gov.br/media/leis/lei-complementar-1552007-12-28-6-12-2017-16-23-28.pdf. Acesso 01 mai. de 2019.

PINTO, L. M. C. Luzimangues: Processos Sociais e Política Urbana na Gênese de uma "Nova Cidade". Dissertação (Doutorado em Desenvolvimento Regional) - Programa de Pós-Graduação em Desenvolvimento Regional, Universidade Federal do Tocantins, PPGDR/UFT, Palmas, 2012.

PIERSON, P. Increasing returns, path dependence, and the study of Politics. The American Political Science Review, v. 94, n. 2, jun. 2000.

PORTES, A. Instituciones y desarrollo: una revisión conceptual. Cuadernos de Economia, v. 25, n. 45, 2006. 
PUTNAM, R. D. Comunidade e Democracia: a experiência da Itália moderna. 2 ed. Rio de Janeiro: editora FGV, 2000.

RODOVALHO, S. A. Palmas, do projeto ao plano: o papel do planejamento urbano na produção do espaço. Dissertação (Mestrado em Desenvolvimento Regional). Universidade Federal do Tocantins. PPGDR/ UFT: Palmas, 2012.

RODOVALHO, S. A.; ROCHA SILVA, M. A. da. RODRIGUES, W. Planejamento urbano participativo e gestão democrática em Palmas (TO) à luz da democracia deliberativa. URBE, Rev. Bras. Gest. Urbana, Curitiba, v. 11, e20190072, 2019. Disponível em: http://www.scielo.br/scielo.php?script=sci_arttext\&pid=S217533692019000100285\&lng=en\&nrm=iso. Acesso em 18 dez 2019. Epub Dez 09, 2019. http://dx.doi.org/10.1590/2175-3369.011.e20190072.

RODOVALHO, S. A.; ROCHA SILVA, M. A. da. A cidadania insurgente na revisão do plano diretor participativo de Palmas-TO. In: Seminário Internacional Projetar: Arquitetura e Cidade: Privilégios, Conflitos e Possibilidades, 2019, Curitiba-PR. Anais do $9^{\circ}$ Seminário Internacional Projetar, 22 a 25 de outubro de 2019, 2019. v. 3. p. 187195.

RODOVALHO, S. A. A política urbana como instituição: o caso do planejamento e gestão urbanos em Palmas (TO) pós-Estatuto da Cidade. Tese (Doutorado em Desenvolvimento Regional). Universidade Federal do Tocantins. PPGDR/ UFT: Palmas, 2020.

RODRIGUES, W.; OLIVEIRA, T. J. A. O norte do Goiás antes do Tocantins: as decisões do estado que influenciaram no processo de criação desta nova unidade da federação. In: Fronteiras, Dourados, MS, v.15, n.26, p.57-71, 2013. Disponível em: <http://ojs.ufgd.edu.br/index.php/FRONTEIRAS/article/viewFile/2818/1869>. Acesso em: 13 jan. 2020.

SCHMIDT, B. V. O Estado e a política urbana no Brasil. Porto Alegre, Ed. Da Universidade, UFRGS, L\&PM, 1983.

SCHNEIBERG, M.; LOUNSBURY, M. Social movements and institutional analysis. In: GREENWOOD, R., OLIVER, C., SAHLIN, K., SUDDABY, R. (Eds.). The handbook of organizational institutionalism, Sage Publications, London, 2008, pp. 650-672.

SOUZA, M. L. Mudar a cidade: uma introdução crítica ao planejamento e a gestão urbanos. 7 Ed. Rio de Janeiro, Bertrand Brasil. 2010.

TANG, S. A General Theory of Institutional Change. London: Routledge, 2011.

VELASQUES, A. B. A. A Concepção de Palmas (1989) e a Sua Condição Moderna. Tese (Doutorado em Urbanismo). Universidade Federal do Rio de Janeiro. PROURB/ UFRJ: Rio de Janeiro, 2010. 
VIEIRA, K. da C. Apropriação privada e valorização imobiliária na "orla" de PalmasTO: onde e quando os projetos disfarçam os verdadeiros planos. Dissertação (Mestrado em Ciências do Ambiente). - Programa de Pós-Graduação em Ciências do Ambiente, Universidade Federal do Tocantins, Palmas, 2019.

Sarah Afonso Rodovalho. Doutora em Desenvolvimento Regional. Professora Adjunta e Pesquisadora do Curso de Arquitetura e Urbanismo. Universidade Federal do Tocantins, Campus Universitário de Palmas, Quadra 109 Norte, Avenida NS 15, Bloco 1 - Coordenação do Curso de Arquitetura e Urbanismo, Plano Diretor Norte, CEP: 77001090 - Palmas, TO - Brasil. sarahrodovalho@uft.edu.br

Monica Aparecida da Rocha Silva. Doutora em Ciências Sociais. Professora Adjunta e Pesquisadora do Programa de Pós graduação em Desenvolvimento Regional. Universidade Federal do Tocantins, Campus Universitário de Palmas, Quadra 109 Norte, Avenida NS 15, Prédio do Programa de Pós graduação em Desenvolvimento Regional, Plano Diretor Norte, CEP: 77001090 - Palmas, TO Brasil.monicars@uft.edu.br@uft.edu.br

Como citar: RODOVALHO, Sarah Afonso; ROCHA SILVA, Mônica Aparecida da. Política Urbana como Instituição: complexidades e limitações na implementação do Plano Diretor Participativo de Palmas (2007) para viabilizar uma mudança institucional. Redes (St. Cruz Sul, Online), Santa Cruz do Sul, v. 25, p. 1576-1602, nov. 2020. ISSN 1982-6745. doi:https://doi.org/10.17058/redes.v25i4.15170.

\section{CONTRIBUIÇÃO DE CADA AUTORA}

A primeira autora contribuiu com a fundamentação teórico-conceitual e problematização; pesquisa de dados e análise estatística; elaboração de figuras e tabelas; elaboração e redação do texto; seleção das referências bibliográficas

A segunda autora contribuiu com a fundamentação teórico-conceitual e problematização; elaboração e redação do texto; e seleção das referências bibliográficas.

Fontes de financiamento: não se aplica. 